\title{
Tobacco money sparks squabble at California universities
}

A row is brewing between University of California (UC) administrators and faculty members at the UC's individual schools over whether to accept money given by tobacco manufacturers such as Lorillard Tobacco and Philip Morris.

The UC adminsitration has said that bans against accepting tobacco money violate academic freedom. But in response to faculty complaints, the matter is under review until 14 March, when the UC academic council will resolve the issue.

"In very short order this is going to explode," says Stanton Glantz, professor of medicine and co-chief of the Tobacco Control Program of the UC San Francisco Comprehensive Cancer Center. "It's going to be a very unpleasant fight."

Since the 1950s, tobacco companies have poured millions of dollars into university research. For instance, the University of California in 2004 received about \$2.4 million in research funding from the tobacco industry.

But saying the industry has a long history of manipulating scientific research and producing fraudulent data, several institutions - including the Karolinska Institute in Sweden, the University of Geneva, at least nine Australian universities and more than 15 US institutions - have established bans against funds from the industry.

The UC San Diego Department of Family and Preventive Medicine banned tobacco money in January 2003. Since then, five other departments in the UC system have followed suit.

But UC administrators say that such bans violate a fundamental, core value of the university: academic freedom. UC President Robert Dynes has said that no department should be allowed to refuse money based on the source of funding.

"Academic freedom has to be absolute or no one has it," adds Lawrence B. Coleman, vice provost for research at the University of California.

The administration is required to seek faculty advice on policy, so the question was brought to the academic council, which declared the bans "unacceptable" and "a dangerous precedent." If the council upholds its initial decision - and Coleman predicts it will—it could signal an end to the bans.

If that happens, "it will be the first time anywhere in the entire world" that a university overrules a faculty decision not to take tobacco money, notes Glantz.

Administrators at Ohio State University, Johns Hopkins University and Harvard University all support the bans at their schools of public health. "[The tobacco industry] specifically funds things to obfuscate the scientific data relating tobacco smoke to health effects," says Alfred Sommer,

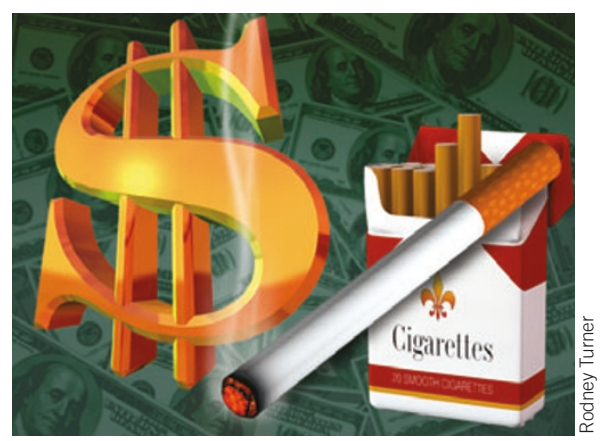

come of the study, and that he was "blindsided" by the vehement attacks against his work.

For his study, Enstrom used a database compiled by the American Cancer Society. But the organization has said that the dataset is not appropriate for analyzing the effects of secondhand smoke. Partly in response to Enstrom's study, it recently barred its grant recipients from accepting tobacco money.

Some researchers worry about establishing a precedent from banning funds from any particular organization. "I think it is not right to demonize one industry," says Michael Kleinman, adjunct professor of community and environmental medicine at the University of California at Irvine.

Others say that academic freedom is being invoked to obscure a larger issue. "What the policy really does is to create no internal forum in which someone like [Glantz] could raise the issue of whether the university is being corrupted, whether by a tobacco company or the pharmaceutical industry, or other sponsor, donor or contractor," says Robert Meister, professor of political science at the UC Santa Cruz.

The dispute might ultimately go to the UC Board of Regents, who in 2001 voted in a university-wide ban on tobacco investment.

Charlotte Schubert, Washington D.C.

\section{Spain launches cancer research project}

Spain's Catalan government has approved a collaborative effort on cancer research with New York's Memorial Sloan-Kettering Cancer Center.

The regional government is set to provide $\$ 34$ million over four years to fund a new program on metastasis research at the Barcelona-based Institut de Recerca Biomèdica (IRB). The program will focus on translational research on metastasis and involve up to eight research teams, including one led by Catalan Joan Massagué, chairman of Sloan-Kettering's Cancer Biology \& Genetics Program.

"If we intend to establish a program coordinated between Barcelona and New York, then the standards of quality and productivity must be similar," says Massagué, who has been an advisor of the IRB for the past few years.

Massagué's lab at Sloan-Kettering studies the role of the TGF-beta signaling pathway in cell regulation and disease and, more recently, the mechanisms for tissue-specific metastasis. At his lab in New York, he coordinates an international program with 250 researchers and an annual budget of $\$ 30$ million.

“Massagué's work on metastasis represents a fantastic opportunity to bring together cancer researchers nationwide," says Francisco Real, an oncology researcher at Barcelona's Municipal Institute of Medical Research. But the government should also promote other, more low-profile projects, Real adds. "This kind of actions of the government to try to respond to the project of a high-profile Spanish researcher rather than the existence of a long-term scientific effort is deplorable."

Spain has unsuccessfully tried to lure Massagué several times. In October 2004, when Massagué was being honored for winning the highest scientific award in Spain, he said research in Spain is "underdeveloped" and that the work he was undertaking at New York would be "unthinkable" in his native country.

Barcelona's Hospital Vall d'Hebrón will provide the new IRB program with 3,500 tumor samples to help researchers identify clinical and genetic markers for metastasis. This might help oncologists predict which tumors are most likely to metastatize and when, thereby anticipating both prevention and treatment.

Xavier Bosch, Barcelona 